\title{
経済分析に基づく 民事紛争への保険利用の問題と課題
}

池田康弘

\section{ロアブストラクト}

本論文は，弁護士費用保険をめぐる潜在的被害者（依頼者，被保険者）, 弁護士，保険者の各当事者の利得構造とインセンティヴ，および当事者間の 情報の非対称性に着目し，民事紛争への保険利用の問題と課題を経済分析に よって明らかにする。

本論文の考察の内容と主な結論は次のとおりである。まず，保険料が保険 数理的に公正であれば，弁護士費用保険に加入未加入のどちらにせよ，依頼 者の期待利得は同じとなり, 弁護士探索の費用がかからない分だけ被保険者 の期待利得が高くなる。次に，成果報酬の弁護士報酬は，弁護士のモラルハ ザードを阻止できるが，契約の不完備性から生じる被保険者と弁護士の暗黙 の結託による弁護士費用の過大請求がもたらされ，他方，固定報酬の場合は， 弁護士のモラルハザードを回避できないが，社会的に正の外部性をもつ事件 にも対処できる可能性がある。さらに，弁護士費用保険は経済的利益をめぐ る原告弁護士と被告弁護士間の暗黙の結託の余地を与え，弁護士費用の過大 請求を許してしまう可能性をもつ。最後に，依頼者保護基金の制度設計は良 質な弁護士を確保するための装置となりうる。保険制度設計者は上記の事柄 を認識する必要がある。

\section{ロキーワード}

并護士費用保険，情報の非対称性，経済的利益

※平成28年10月29日の日本保険学会大会（立命館大学）報告による。

/ 平成29年 3 月 6 日原稿受領。 


\section{1. はじめに}

本論文は，弁護士費用保険をめぐる潜在的被害者（依頼者，被保険者）， 弁護士，保険者の各当事者の利得構造とインセンティヴ，および情報の非対 称性に着目し，民事紛争への保険利用の問題と課題について経済分析によっ て明らかにするものである。

弁護士費用保険とは，あらかじめ保険契約において保険料を支払った被保 険者（Insured）が損害を被ったとき，相手方に損害を請求すべく依頼した 弁護士への弁護士報酬，すなわち被保険者の弁護士費用を保険者（Insurer） が保険金支払によって補償する保険契約である ${ }^{1)}$ 。例えば，具体的に次のよ うな例を想定しょう。自動車事故で, 相手方に100パーセントの過失があり， 被害者本人には全く責任がない事故, いわゆるもらい事故のケースにおいて, 被害者本人は相手方加害者, 相手方の加入する保険者, またはその弁護士と 直接交涉しなければならない。被害者本人では原状回復もままならないが, 弁護士にその任務を依頼すれば，弁護士への報酬，すなわち依頼者にとって の弁護士費用がかかるが，それは保険者によって補償されるので，依頼者に とって費用面において安心な制度であると言える。もちろん，費用負担がな いだけでなく，本人には到底できない弁護士による高い回収の見込みが得ら れる点も弁護士費用保険のメリットである。

近年，并護士費用保険は，日常生活におけるさまざまなトラブル等におい て利用される保険商品としても開発され，市民の司法へのアクセスの拡充， 弁護士の業務の拡大，および新たな保険市場の創設など，社会的に注目され る仕組みであり，今後の普及，さらなる発展が注目されるところである。

しかしながら，昨今の弁護士費用保険の開発と普及に伴い，保険利用にお ける過大な弁護士費用請求や少額事件における訴訟件数の増大などが問題と されている ${ }^{2)}$ 。また，依頼者の財産を着服するといった有責の弁護士とのト

1）山下 (2011), 大井 (2015), 内藤（2016）, 應本（2016）等を参照。

2）山下（2011）499頁，大井（2017）は，弁護士費用保険を利用した訴訟増加 
ラブルから依頼者を救済する動きとしての保護基金等が検討されているもの の，まっとうな弁護士のインセンティヴを減退させるといった批判も寄せら れている ${ }^{3)}$ 。経済学的に見れば, 少額訴訟の増加や依頼者と弁護士の間での トラブルの発生は各々の当事者のインセンティヴの問題とその間で生じる情 報の非対称性に起因する問題と捉えることができる。すなわち，モラルハザ ードと逆選択の問題である。モラルハザードとは依頼者が代理人の行動を直 接監視できないことから生じる状況で，私的情報をもつ代理人の機会主義的 行動により，代理人に本来あるべき行動を取らせるのが困難な状況をいう。 経済学はこの代理人の行動を倫理道徳の欠如の問題だけに帰着せず，制度や しくみの問題として捉えることを基本的解決策と考える ${ }^{4)}$ 。逆選択とは属性 （夕イプ）が外部から見えないゆえ，良質でない夕イプの当事者が市場に生 き残るという意味である。これらの状況は代理人等の当事者の行動やタイプ がその代理人本人にしか分からないという情報偏在によって引き起こされる。

本論文では，なぜ上記のような問題が引き起こされるのかについて，并護 士費用保険をめぐる各当事者の利得構造を明確にしたうえで，それぞれの当 事者のインセンティヴを踏まえ，モラルハザード，暗黙の結託，そして逆選 択の状況について指摘しつつ, それらの問題と課題について検討する。

本論文の構成は次のとおりである。第 2 節では，弁護士報酬の根拠が述べ られる。続く第 3 節では, 状況設定と各当事者の利得構造を明らかにし, 第 4 節において，それらの問題と課題を踏まえた考察が展開される。最後の第 5 節において，若干のコメントを述べることにする。

の濫訴の可能性を指摘する。濫訴の定義は, 内外に拈いてさまざまであるが,

Rasmusen（1998）によれば, “Nuisance Suit or Frivolous Suit”を司法プロセ スが当分の間修正され得ず，見込回収額が自らの訴訟費用にペイしないことを 原告が知っているのにもかかわらず提訴された勝ち目の低い訴元，と定義する。 この定義からすると，被保険者の訴訟費用等を補償する弁護士費用保険は，費 用負担がない分，ある意味で被保険者を気楽（frivolous）に提訴に至らしめて いると言えるかもしれない。

3 ）依頼者保護基金の制度設計の検討については，山下（2017）を参照。

4 ）神取（2014）405-406頁を参照。 


\section{2. 弁護士報酬の根拠}

本節では，弁護士費用保険のあり方を検討するために，并護士報酬の根拠 となりうるいくつかの要素について述べることにする。周知のとおり, 弁護 士報酬は2004年 4 月より自由化された。当事者間の合意が成されていれば, 公序良俗に反しない限り，弁護士報酬は基本的にどんなものでも良いと考元 られる。ただし，従前の報酬規程は撤廃されたとはいえ，弁護士報酬には何 らかの根拠づけが必要となるであろう。当事者間で合意が形成される構成要 素が明らかにされなければならない。

\section{（1） 経済的利益 一弁護士の貢献度一}

端的に言ってしまえば, 并護士報酬は弁護士の貢献によってもたらされた 利益に基づき算出されるべきであると考えるのは自然の発想であろう。とは いえ，弁護士が任務遂行に奮闘努力しても成果を出せなかった場合，すなわ ち，依頼者に何らの成果ももたらされなかった場合でも，弁護士への任務遂 行業務に対する対価は支払われなければならないであろう。努力したにもか かわらず，成果が出ないのは，そもそも依頼された事件そのものがほとんど 成果を生まない性質のもの，いわゆる質の問題 ${ }^{5}$ が原因であるのか，もしく は，弁護士の責めに帰さないさまざまな不測の事態の表れによるものである のかもしれない。そこで，弁護士によってもたらされた成果に基ついてどの ように弁護士報酬が決められるのかについて，まず数值例を用いて考えてみ たい。

ある事件で被害を被った被害者（依頼者）の損害額を800万円としよう。 そして, 被害者本人が独力で加害の相手方を訴え, 裁判あるいは和解によっ て200万円回収できた（あるいはできる）としよう。これで損害額は600万円 になった。さて, この被害者が弁護士に原状回復を依頼した場合, 仮に, こ

5） Scotchmer \& Rubinfeld（1990）は，事件の質（quality）に関する依頼者と 弁護士との間の情報非対称性について考察している。 
の弁護士によって損害額800万円全額を相手方から回収できたとする。この 時点で被害者の損害は完全に填補されている。このとき，この弁護士の貢献 は，依頼者本人の回収額200万円をデフォルト（初期值）として捉えれば, 弁護士による回収額800万円からこの依頼者による回収額200万円を差し引い た值，すなわち 800 万円 -200 万円 $=600$ 万円である。この回収額の差額の 600 万円は弁護士の貢献によって得られたものとみなされる。この意味で, 回収 額の差額600万円は弁護士業界の専門用語で, 訴訟もしくは和解による「経 済的利益」と呼ばれる ${ }^{6)}$ 。したがって, 弁護士報酬は基本的に弁護士の貢献 度を表す経済的利益に基づき算定されることになる。前述したように，経済 的利益は弁護士によってもたらされたものであるが，その額の大小が決まる のは事件の質によることもありうることに留意すべきである7。

\section{（2）成果報酬と固定報酬}

弁護士の任務遂行努力によってもたらされた成果，すなわち経済的利益に 基づき算出される報酬は成果報酬（Contingent Fees）である。弁護士報酬 が成果報酬であるとき，経済的利益に基づき弁護士は報酬を得るが，成果が 出ていないとき，すなわち経済的利益がゼロのとき，弁護士は報酬を得られ ない。したがって，弁護士による成果が出されないときは，依頼者に原状回 復はもたらされないが弁護士費用もかからないのである。

他方, 弁護士の任務遂行の努力, そしてその成果の如何にかかわらず決め られる報酬は固定報酬（Fixed Fees）である。このとき，弁護士は成果にか かわらず報酬を受取ることになり，依頼者は成果が出た場合でも出なかった 場合でも弁護士費用を負担することになる。

6）東京弁護士会法友全期会報酬基準研究会（2004）21頁は，経済的利益を弁護 士の事件処理によって確保された利益と説明している。

7）弁護士の報酬に関する規定第 2 条は「弁護士等の報酬は，経済的利益，事案 の難易, 時間及び労力その他の事情に照らして適正かつ妥当なものでなければ ならない」としている。 


\section{3. 弁護士費用保険をめぐる状況設定と各当事者の利得構造}

本節では，并護士費用保険をめぐる状況を捉え，事故の潜在的被害者（弁 護士に依頼する場合は依頼者，保険に加入する場合は被保険者），弁護士， および保険者の各当事者の利得構造について確認する。

\section{（1） 状況の流れと記号の定義}

状況の流れを述べる。まず，潜在的被害者が，あらかじめ弁護士費用保険 に加入するか，あるいは加入しない。次に，被害者が事故に遭い損害を被る か, 事故に遭わないかである。続いて, 被害者が事故の損害を被った場合, 保険加入の被害者（被保険者）は保険者から紹介された弁護士に原状回復を 依頼し, 保険未加入の被害者は自分で弁護士を探し出し, 弁護士に原状回復 を依頼する。事故に遭わず被害がなかった場合は現状のままである。

記号の定義を行う。潜在的被害者の初期資産を $\mathrm{T}(>0)$, 被害者の事故の 損害額を $\mathrm{H}(>0)$, 事故の発生確率を $\mathrm{q}$, 発生しない確率を $1-\mathrm{q}$ とする。被 害者の原状回復のために回収したものを回収額 $\mathrm{R}(>0)$, そのときの確率を 成功確率 $\mathrm{p}$, 回収の成果が挙げられなかったときの確率を失敗確率 $1-\mathrm{p}$ と する。弁護士報酬が成果報酬の場合で，被害者の損害が弁護士の任務遂行活 動によって補填された（成果が出た）とき, 回収額 $\mathrm{R}$ は弁護士の貢献度, す なわち経済的利益であり ${ }^{8)}$ ，その経済的利益のある一定割合 $(\beta(0 \leqq \beta \leqq 1)$ と表す）を弁護士へ報酬として与えるとすれば， $\beta \mathrm{R}$ が弁護士の取り分，す なわち弁護士報酬となる。そのときの確率は $\mathrm{p}$ であるので, 事前の取り決 めに扮いて, 弁護士の取り分は $\mathrm{p} \beta \mathrm{R}(>0)$ となる。弁護士報酬が固定報酬の 場合は，経済的利益の額の如何にかかわらず付与されるものであるから，弁 護士報酬はある一定の額となる。その值を $\alpha(>0)$ とする。

8）ここでは，被害者本人が自分で相手方保険者（あるいは相手方弁護士）と交 涉した場合，一銭も回収できない場合を想定した。したがって，回収額 Rが 経済的利益となる。 


\section{（2）保険者期待利得と公正保険料}

以上の設定に基づき，保険者の利得構造について考察する。先に述べたよ うに，弁護士費用保険とは，保険者が被保険者から保険料を徵収し，事故が 起きその解決を依頼された弁護士への弁護士報酬（被保険者の弁護士費用） を保険者が保険金として補償するという契約のことである。ゆえに，保険者 の収入は被保険者の支払う保険料であり，そして被保険者一人当たりの弁護 士費用の請求額（期待値）が保険者の期待保険金支払額となる。すなわち, 保険者の期待保険金支払額は期待弁護士費用となる。したがって，保険料と 期待弁護士費用の差を保険者の期待利得と定義すると，保険者の期待利得は 次のように

$$
\text { 保険者期待利得 }=\text { 保険料 }- \text { 期待弁護士費用 }
$$

と表される。保険者は少なくとも期待利得が非負となるように保険料と期待 保険金支払額を設定するであろう。ここでは，保険料が保険者の収支均等原 則に従って設定されるとしよう。すなわち，保険者は保険料を期待弁護士費 用に等しくするよう設定する。このように設定された保険料は公正保険料 (Fare Premium)，あるいは純保険料と呼ばれる9”。保険者は請求される弁 護士費用を被保険者への保険金支払の形で負担するが，その額は被保険者の 弁護士費用，すなわち并護士への并護士報酬が成果報酬であるのか，あるい は固定報酬であるのかによって異なる。以下では, 弁護士報酬が成果報酬, 固定報酬の場合に分けて，公正保険料を導出する。

まず，弁護士報酬が成果報酬の場合を考える。確率 q で事故が発生し， 被保険者は損害 $\mathrm{H}$ を受ける。そのもとで，保険者は被保険者に弁護士の紹

9）この保険料は保険数理的に公正な保険料とも呼ばれる。今泉・須賀・渡辺 （2001）349頁，ピンダイク\&ルビンフェルド（2014）213頁を参照。実際の保 険料は公正保険料とその他の実務的費用から成り立つ。例えば，保険者が被保 険者に弁護士を紹介する業務にもコストがかかっている。 
経済分析に基づく民事紛争への保険利用の問題と課題

介を行い, 被保険者は弁護士に損害の回収を依頼する。そこで, 被保険者の 損害に対して弁護士が任務遂行の努力を行い，確率 $\mathrm{p}$ で回収額 $\mathrm{R}$ がもたら されるとしよう。このとき, 経済的利益は $\mathrm{R}$, 并護士報酬は $\beta \mathrm{R}$ とる。保 険者の保険金支払に上限がなければ，并護士費用保険金は $\beta \mathrm{R}$ となる。他方， 確率 1-p で成果を挙げられないとすれば，経済的利益はゼロ，連動して弁 護士報酬はゼロとなるので，ゆえに，并護士費用保険金はゼロとなる。確率 1-q で事故は発生せず, 被保険者は損害を受けないので, その場合は当然, 保険者は被保険者へ保険金を支払わずに済む。以上から，保険者の被保険者 への期待保険金支払額（期待弁護士費用）は， $(1-\mathrm{q}) \times 0+\mathrm{q}[\mathrm{p} \beta \mathrm{R}+(1-\mathrm{p})$ $(\beta \times 0)]=\mathrm{qp} \beta \mathrm{R}$ となり，保険者はこの值に見合うよう収入としての保険料 を設定する。この保険料を $\mathrm{w}^{\mathrm{C}}$ と表すと, 公正保険料は次式となる。

$$
\mathrm{w}^{\mathrm{C}}=\mathrm{qp} \beta \mathrm{R}
$$

すなわち, 并護士報酬が成果報酬の場合の公正保険料 $\mathrm{w}^{\mathrm{C}}$ は, 損害の発生確 率，原状回復の成功確率，経済的利益の弁護士の取り分割合，および経済的 利益の積という形で構成されることがわかる。

次に，弁護士報酬が固定報酬の場合をみる。事故の発生と損害の状況は成 果報酬の場合と同様である。このとき, 弁護士が成果を出すか出さないかに かかわらず，并護士報酬は $\alpha$ となる。損害が発生しない場合，成果報酬の ケースと同様に, 保険者の保険金支払額はゼロとなる。ゆえに, 保険者の保 険金支払額に上限を設けなければ，保険者の期待保険金支払額（期待弁護士 費用）は, $(1-\mathrm{q}) \times 0+\mathrm{q}[\mathrm{p} \alpha+(1-\mathrm{p}) \alpha]=\mathrm{q} \alpha$ となる。并護士報酬が固定 報酬の場合の公正保険料を $\mathrm{w}^{\mathrm{F}}$ と表すと, このときの公正保険料は次式を満 たすように設定される。

$$
\mathrm{w}^{\mathrm{F}}=\mathrm{q} \alpha
$$


すなわち, 弁護士報酬が固定報酬の場合, 公正保険料 $\mathrm{w}^{\mathrm{F}}$ は事故の発生確率 と固定報酬額の積によって構成される。

\section{（3）被保険者の期待利得}

前項では，保険者の利得構造を明らかにした上で，それぞれの報酬形態に よって公正保険料が異なることを導いた。本項では，その公正保険料を用い て弁護士費用保険に加入している被保険者の期待利得を求める。弁護士報酬 の契約内容が成果報酬である場合と固定報酬の場合とに分けて導出しよう。

まず，弁護士報酬が成果報酬の場合を考える。事故発生確率 $\mathrm{q}$, 弁護士に よる損害回収の成功確率 $\mathrm{p}$, 被保険者の資産 $\mathrm{T}$, 損害額 $\mathrm{H}$, 回収額 $\mathrm{R}$, およ び弁護士の報酬割合 $\beta$ は前項の設定と同様とする。ただし，回収額は損害額 を超えない, すなわち $\mathrm{H}>\mathrm{R}$ とする。さて, 弁護士によって損害の回収につ き成果を収めたとき，弁護士報酬（被保険者の弁護士費用）は $\beta \mathrm{R}$ とり， 保険者がその弁護士費用を全額負担するとした場合，弁護士費用保険金は $\beta \mathrm{R}$ となる。そして, 弁護士報酬が成果報酬のときの保険料を公正保険料 $\mathrm{w}^{\mathrm{C}}$ とする。以上から, 弁護士報酬が成果報酬の場合の被保険者の期待利得 $\left(\pi_{\mathrm{d}}{ }^{\mathrm{C}}\right.$ と表す) は, 次式となる。

$$
\pi_{d}^{c}=(1-q) T+q[p(T-H+R-\beta R+\beta R)+(1-p)(T-H)]-w^{c}
$$

保険料が公正保険料（ $\mathrm{w}^{\mathrm{C}}=\mathrm{qp} \beta \mathrm{R} ）$ であるので，上式を整理して書き換える と次のようになる。

$$
\pi_{\mathrm{d}}^{\mathrm{c}}=(1-\mathrm{q}) \mathrm{T}+\mathrm{q}[\mathrm{T}-\mathrm{H}+\mathrm{pR}-\mathrm{p} \beta \mathrm{R}]
$$

次に，弁護士報酬が固定報酬のケースを見る。各事象の值と確率と成果報 酬の場合と同様である。弁護士報酬が固定報酬のときの保険料を公正保険料 $\mathrm{w}^{\mathrm{F}}$ とすると, 被保険者期待利得（ $\pi_{\mathrm{d}}^{\mathrm{F}}$ と表す）は, 


$$
\pi_{\mathrm{d}}^{\mathrm{F}}=(1-\mathrm{q}) \mathrm{T}+\mathrm{q}[\mathrm{p}(\mathrm{T}-\mathrm{H}+\mathrm{R}-\alpha+\alpha)+(1-\mathrm{p})(\mathrm{T}-\mathrm{H})]-\mathrm{w}^{\mathrm{F}}
$$

となる。上式に公正保険料 $\left(\mathrm{w}^{\mathrm{F}}=\mathrm{q} \alpha\right)$ を代入すると, 被保険者期待利得は 次式となる。

$$
\pi_{\mathrm{d}}^{\mathrm{F}}=(1-\mathrm{q}) \mathrm{T}+\mathrm{q}[\mathrm{T}-\mathrm{H}+\mathrm{pR}-\alpha]
$$

\section{（4）保険未加入の依頼者の期待利得}

前項では，事故の被害者が弁護士費用保険に加入しているケースを扱った が，今度は，弁護士費用保険に未加入の被害者（以後, 依頼者と呼ぶ）が独 力で弁護士を探し，損害の原状回復をその弁護士に依頼する場合の依頼者期 待利得について考察する。前項の被保険者のケースとの違いは, 保険未加入 であるので事故が生じ損害を被ったとき，自らで弁護士を探しその労力（弁 護士探索コスト ${ }^{10)} ： \mathrm{E}$ と表す）がかかり，弁護士費用は自らが負担するとい うものである。

まず，弁護士報酬が成果報酬のケースをみてみよう。相違点以外の設定は 前項と同様である。このとき保険未加入の依頼者期待利得（ $\pi_{\mathrm{v}}{ }^{\mathrm{c}}$ と表す）は 次式となる。

$$
\pi_{\mathrm{v}}^{\mathrm{c}}=(1-\mathrm{q}) \mathrm{T}+\mathrm{q}[\mathrm{p}(\mathrm{T}-\mathrm{H}+\mathrm{R}-\beta \mathrm{R})+(1-\mathrm{p})(\mathrm{T}-\mathrm{H})-\mathrm{E}]
$$

上式を整理すると，

$$
\pi_{\mathrm{v}}^{\mathrm{c}}=(1-\mathrm{q}) \mathrm{T}+\mathrm{q}[\mathrm{T}-\mathrm{H}+\mathrm{pR}-\mathrm{p} \beta \mathrm{R}-\mathrm{E}]
$$

10）并護士探索コストには，保険加入時と比べて弁護士費用が補償されないとい う依頼者の心理的重荷などを含むことも考えられる。 
となる。

次に，弁護士報酬が固定報酬の場合をみよう。成果報酬の場合と同様に弁 護士を自分で探し，弁護士費用は自らで負担する。固定報酬であるので弁護 士によって成果が出されるか出されないにかかわらず，依頼者は弁護士費用 を負担しなければならない。したがって，并護士報酬が固定報酬の場合にお ける保険未加入の依頼者の期待利得（ $\pi_{\mathrm{v}}^{\mathrm{F}}$ と表す）は

$$
\pi_{\mathrm{v}}^{\mathrm{F}}=(1-\mathrm{q}) \mathrm{T}+\mathrm{q}[\mathrm{p}(\mathrm{T}-\mathrm{H}+\mathrm{R})+(1-\mathrm{p})(\mathrm{T}-\mathrm{H})-\alpha-\mathrm{E}]
$$

となり，上式を整理すると次式を得る。

$$
\pi_{\mathrm{v}}^{\mathrm{F}}=(1-\mathrm{q}) \mathrm{T}+\mathrm{q}[\mathrm{T}-\mathrm{H}+\mathrm{pR}-\alpha-\mathrm{E}]
$$

\section{(5) 弁護士の期待利得}

本項では，弁護士の期待利得について定式化する。まず，弁護士報酬は弁 護士費用保険に加入の場合は保険者から，未加入の場合は依頼者（被害者） から弁護士に支払われる。そして，いずれの場合であっても，仕事の依頼を 受けた弁護士は任務遂行の努力を行う。もちろん，その努力行使に伴い弁護 士には労力がかかる。この労力を弁護士の任務遂行費用と呼べば, 弁護士の 期待利得は次のように定義できる。

$$
\text { 弁護士期待利得 }=\text { 弁護士報酬 }- \text { 任務遂行費用 }
$$

一見すると，弁護士にとって，任務遂行の対価としての報酬は依頼者が保 険に加入していようといまいと，すなわち，保険者から支払われようと依頼 者本人から支払われようと，何ら変わりはないと思われる。ところが，依頼 者の利得構造の差異から理解されるように，保険未加入の依頼者は弁護士探 索コストがかかる分，相対的に弁護士に依頼するインセンティヴは過小なも 
経済分析に基づく民事紛争への保険利用の問題と課題

のとなる。したがって, 保険未加入の依頼者による并護士への依頼数は, 保 険加入の被保険者による并護士への依頼数よりも少なくなることにに留意し なければならない。この詳細は次節以降で展開される。

\section{4. 考 察}

本節では， 2 節および 3 節で行った各当事者の利得構造を踏まえ，弁護士 費用保険の開発と普及における問題と課題について考察を行う。

\section{（1）司法アクセスの拡充, 弁護士の業務拡大, および保険市場の創出}

まず成果報酬のケースにおいては，保険加入の場合の依頼者の期待利得 (4)' 式と保険未加入の場合の依頼者の期待利得 (6)' 式を比較すると, 事故が起 きた際，依頼者が弁護士を探す探索費用分だけ，保険未加入の依頼者の期待 利得は小さくなっている。固定報酬の場合も同様である。この意味で, 保険 未加入の潜在的被害者は，保険加入の場合よりも并護士に依頼するインセン ティヴが低いことがわかる。このことは被害者を泣寝入りさせるなど司法へ のアクセスを阻害する要因となり，そのことは并護士への依頼数が少なくな ることを意味する。したがって，弁護士費用保険は，市民の司法へのアクセ スの拡充, 弁護士業務の拡大, そして新たな保険市場の創出という３つの可 能性を有していることになる。

\section{（2）成果報酬，固定報酬，およびモラルハザードの構造}

并護士報酬の内容は，并護士だけでなく，被保険者（依頼者）と保険者の 各々に影響を与える。前節で見たように，弁護士の期待利得は弁護士報酬と 任務遂行費用の差であった。各主体の利得構造を踏まえ，モラルハザードの 構造について明らかにする。

まず，弁護士にとって成果報酬と固定報酬のどちらが良いであろうか。任 務遂行費用を記号で表すと, 并護士の期待利得は, 固定報酬の場合 $\pi_{\mathrm{A}}{ }^{\mathrm{F}}=\alpha$ 
$-\mathrm{g}(\mathrm{e})$ であり，成果報酬の場合 $\pi_{\mathrm{A}}{ }^{\mathrm{C}}=\mathrm{p}(\mathrm{e}(\beta)) \beta \mathrm{R}-\mathrm{g}(\mathrm{e}(\beta))$ となる ${ }^{11)}$ 。た だし， e は弁護士の任務遂行の努力， $\mathrm{g}(\mathrm{e})$ は任務遂行の努力費用である ${ }^{12)}$ 。 固定報酬 $\alpha$ が成功報酬 $\mathrm{p}(\mathrm{e}(\beta)) \beta \mathrm{R}$ よりも大きいとき, 弁護士は固定報酬を 選好する。このとき弁護士の努力レベルは過少となるので13), 弁護士のモラ ルハザードが生じる。このとき, 并護士の過少な努力レベルに連動して依頼 者の期待回収額 $\mathrm{p}(\mathrm{e}) \mathrm{R}$ も低下している。反対のとき, 成果報酬 $\beta$ によって 弁護士の努力が決まりそして期待回収額が決定されるので，そのうえで弁護 士は相応の努力を行使することになる ${ }^{14)}$ 。ただし，損害額が少額のとき， $\alpha>\mathrm{p}(\mathrm{e}(\beta)) \beta \mathrm{R}$ となる可能性が高くなるので, 并護士は努力に依存しない固 定報酬を選好する。

次に，依頼者にとってどちらの并護士報酬が良いであろうか。依頼者の期 待利得から期待回収額と弁護士費用（并護士報酬）の差の部分を抽出すると, 成果報酬の場合 $\mathrm{p}(\mathrm{e}(\beta)) \mathrm{R}-\mathrm{p}(\mathrm{e}(\beta)) \beta \mathrm{R}$ ，固定報酬の場合 $\mathrm{p}(0) \mathrm{R}-\alpha$ となる。 いずれも弁護士費用は保険者の負担となるので，一見，被保険者は弁護士報 酬の内容や弁護士の任務遂行努力に無関心になると思われる。しかしながら， 被保険者の期待利得は，保険者が費用を補償してくれることにより，成果報 酬のとき $\mathrm{p}(\mathrm{e}(\beta)) \mathrm{R}$ ，固定報酬のとき $\mathrm{p}(0) \mathrm{R}$ となる。このとき，固定報酬の ときの回収額はゼロであるので，明らかに依頼者は成果報酬の弁護士報酬を 用いる。そして, 弁護士の報酬割合 $\beta$ を最大限にすれば弁護士の任務遂行努 力を高く引き出すことができ，それは期待回収額（期待利得）を高くできる のである。したがって, 被保険者は成果報酬を選好し, それを用いて弁護士

11）成果報酬に抢ける弁護士の努力 $\mathrm{e}$ は報酬割合 $\beta$ に依存した関数になっている ことに留意せよ。

12）弁護士の任務遂行に関する努力費用関数 $\mathrm{g}(\mathrm{e})$ の形状は, $\mathrm{g}(0)=0$ （任務遂行 の努力がゼロのときその努力に伴う労力はゼロ）かつ原点に対して凸（努力に 伴う労力は努力が増えれば増えるほど聥増する）とする。

13）このとき，弁護士の任務遂行努力は峳密にはゼロとなる。

14）仮に弁護士の取り分 $\beta$ が1のとき, 弁護士はそうでないときに比べて努力を 行使し，期待回収額は上昇するが，依頼者の取り分はゼロになる。 
経済分析に基づく民事紛争への保険利用の問題と課題

のモラルハザードを制御する。

\section{（3）成果報酬における暗黙の結託と固定報酬における正の外部性}

前項の考察において, 并護士報酬の内容によって被保険者と弁護士の利益 相反が生じることがわかった。成果報酬の弁護士報酬は一般に弁護士のモラ ルハザードを制御できる。しかしながら，その場合でも報酬契約の内容が真 実であるかどうかについて保険者が見抜けない場合はある問題が生じる。い わゆる契約における不完備性の問題である。契約の不完備性とは事前に将来 起こり得るすべての事項を契約内容に列記することができないこと，またで きたとしても多大なコストがかかることをいう。それゆえ，第三者には検証 できない暗黙的な内容が必然的に契約には含まれることになる

弁護士報酬が成果報酬の場合，依頼者と弁護士の間での暗黙の結託により 弁護士費用を過大に請求し，後に両者で山分けをするといった可能性が理論 上起こり得る。このことを数值例で示してみたい。回収額を1000万円とする。 一般的な成果報酬 $\beta$ の割合を 20 パーセントとする。着手金等を除いてシンプ ルな設定をすれば，并護士の取り分は200万円であり，依頼者の取り分は回 収額1000万円から弁護士報酬200万円を差し引いた 800 万となる。保険加入 の被保険者であれば，200万円の弁護士報酬は并護士費用として保険者に請 求できるので，被保険者の取り分は1000万円になる。この場合，并護士は依 頼者または保険者から報酬を得るかの違いだけで，報酬額は同じである。

このことを踏まえて，保険者への弁護士費用の申請を通常よりも割高の30 パーセントの成果報酬で行ったとしよう。そして，実際は被保険者と弁護士 で弁護士報酬を成果報酬20パーセントとして暗黙の取り決めしていたとしよ う。これは金額でいうと，暗黙の取決めの200万円より100万円多い300万円 を并護士費用として保険者に申請したことになる。このとき, 保険で補償さ れるので，いずれにせよ，被保険者の回収額は1000万円である。并護士報酬 20パーセントの際の取り分を基準にこの弁護士費用保険金の差額100万円を 15）細江（2005）4-7頁，ミルグロム\&ロバーツ（1997）134-141頁を参照。 
両者で折半すると，両者の取り分は被保険者は1050万円，弁護士は250万円 となる。また，その差額100万円をすべて弁護士が得ることも被保険者が得 ることも理論上可能である。このような状況は両者にとってパレート改善の 状況になっており，暗黙の結託として理論的に生じうるものであることに留 意する必要がある。契約の不完備性の状況は完全になくすことは難しいけれ ども，弁護士報酬の報酬契約内容の根拠について保険者が十分に確認するこ とが必要となるであろう。

前述したが，弁護士は固定報酬の弁護士報酬を選好し，とくに少額事件の 場合, 回収額 $\mathrm{R}$ は少額であるので, 成果報酬割合が高くても, 弁護士の取 り分は少なくなる可能性がある。しかしながら，損害額の少額の事件であっ てもその事件が他の潜在的被害者へ社会的に望ましい正の外部性を有する事 件であれば，固定報酬の弁護士報酬が保険で利用されたとしても，そのこと は社会的に意義があるかもしれない。その意味で，被保険者にモラルハザー ドをもたらすにせよ，社会的に見れば，固定報酬の弁護士報酬の余地はあり うる。

\section{（4）被告側の弁護士費用保険}

前項までは，被保険者，弁護士，および保険者が被害者である原告当事者 であることを想定していた。本項では，被害者である原告と加害者である被 告の双方が弁護士費用保険に加入しているケースを考える。以下，被害者を 原告，加害者を被告と呼ぶことにする。

原告が被告に対して損害賠償 R の訴えを起こし，原告弁護士と被告弁護 士が各々の当事者の代理人として争うとする。このとき, 被告弁護士は損害 賠償の支払額をできるだけ少なくなるように防御努力をする。仮に被告弁護 士の弁護努力によって完全防禦がなされた場合，すなわち，賠償支払額がゼ ロとなった場合，被告弁護士の貢献度は $\mathrm{R}-0$ によって測られる。すなわち， 被告の経済的利益は $\mathrm{R}$ となる。この被告の経済的利益は原告が求めた賠償 額 R によって決まることがわかるであろう。賠償額は言いがかりの可能性 
経済分析に基づく民事紛争への保険利用の問題と課題

も否定できないが，原告からの賠償請求額が大きければ大きいほど，被告弁 護士の弁護士報酬が成果報酬であれば，被告弁護士は潤うことになる。ここ に原告弁護士と被告弁護士の暗黙の結託の可能性が潜んでいる。すなわち, あくまでも理論上の可能性であるが，ある事件で被告并護士は原告側の過大 な賠償請求を黙認する代わりに，別の事件で立場が替わって原告弁護士とな つたとき過大な賠償請求を行うといった構罒が考えられる ${ }^{16)}$ 。被告と弁護士 が成果報酬の弁護士報酬契約を結んでいた場合 ${ }^{17)}$, それゆえ, 被告の并護士 費用負担は大きくなる可能性がある。このような場合において, 弁護士費用 保険に未加入であれば，被告は報酬契約内容に興味関心を示し，場合によっ ては弁護士にクレームを付けるが，加入していれば，并護士費用は保険者が 補償するので，被告の被保険者は弁護士報酬の内容に関心を示さず，暗黙の 結託による弁護士費用の過大請求がそのままと野放しになる可能性がある。 したがって，このケースにおいては，弁護士費用保険を開発しない，または， 被告と被告弁護士の成果報酬契約は保険として認めないという選択肢を考慮 する必要があるかもしれない。ただし, その代替としての固定報酬もまた被 告弁護士のモラルハザードをもたらし，そして被告が必要以上に賠償支払を することになるのである。

\section{（5） 逆選択の構造とシグナリング}

これまでは，モラルハザード問題について考察してきたが，本項では，逆 選択問題について考察する。序章で述べたように，依頼者に弁護士の良質な サービスが提供されないケース，例えば，極端な場合，弁護士による依頼者 の預り金などの財産の着服など問題のあるケースが少なくないという。この ことは，依頼者が前もって弁護士の質を見抜けないことに起因する逆選択状

16）太田（1997）37頁を参照。太田（1997）は原告弁護士と被告弁護士の暗黙の 結託を指摘したわが国の先駆的文献である。

17）被告とその弁護士が結ぶ成果報酬の弁護士報酬は Reverse Contingent Fees と呼ばれる（Toothman and Ross (2003）pp 183)。 
況から引き起こされると考えられる。こうした有責の弁護士とのトラブルに 対して，依頼者を救済する手段としての基金制度などが検討されている ${ }^{18)}$ 。 これには良質なサービスを提供できる弁護士は賛成できないことかもしれな い。しかしながら, この問題に対する経済学の知見は, 質の良いタイプの弁 護士が自らが良質な弁護士である旨を依頼者，あるいは世間に対してシグナ ルとして発信（シグナリング）するというものである。または，保険者が良 質な弁護士を被保険者に紹介し，被保険者の情報劣位を補足する手立てを用 意することも必要である。このシグナリングは長い目で見れば弁護士に対す る信頼維持につながる可能性がある。

自らが良質な弁護士であるというシグナルが信頼できるシグナルであると 依頼者にわかってもらうには，弁護士は相応の努力をしなければならず，そ れには労力がかかる。そのためには，弁護士が身を粉にして働いていること が依頼者に見えていることなどが要件となる。良質でない并護士は余計に労 力がかかるため良質な弁護士が発信するシグナルを真似できない。それゆえ 良質のタイプとそうでないタイプの弁護士の行動は分離される。

シグナル情報が正しいものであることを依頼者に示すには，各々の弁護士 がコストをかけてシグナルを発信する他ないが, 補完的な手段として, 并護 士の質に関する認証制度の確立や情報偏在を解消すべく情報開示の整備，弁 護士が基金などに保証金を預ける保証金制度の構築などが挙げられよう ${ }^{19)}$ 。

\section{5. おわりに}

わが国の司法制度改革の三本の柱のひとつであった市民の司法へのアクセ 又拡充や弁護士報酬の自由化によって司法はわれわれに身近な存在になった であろうか。そんな中，司法アクセスの拡充を補完する，あるいは倰駕する 可能性を有する弁護士費用保険の登場は社会的にも期待され注目されるとこ ろである。
18）山下（2017）を参照。
19）ヴァリアン（2015）675頁を参照。 
経済分析に基づく民事紛争への保険利用の問題と課題

本論文では，民事紛争への保険利用の問題と課題について経済学的視点か ら考察を行った。市民の司法アクセスの拡充のみならず, 弁護士の業務の拡 大，そして，新たな保険市場の創設は，われわれの生活に密にかかわる社会 的制度設計の一つに挙げられよう。普及と発展における様々な問題を多角的 に吟味し, 経済学的な視点も制度設計の一翼を担う存在となり得ることを期 待したい。

【付記】本論文は, 公益財団法人民事紛争処理研究基金による共同研究助成 の成果の一部である。

(筆者は熊本大学法学部准教授)

\section{参考文献}

今泉博国 ·須賀晃一・渡辺淳一（2001）『ミクロ経済学 基礎と演習』東洋経済新 報社。

大井暁（2015）「弁護士報酬等補償特約の検討」『保険学雑誌』629号153-173頁。 大井暁（2017）「弁護士費用保険を巡る諸問題」『保険学雑誌』636号（本号）。 應本昌樹（2016）『権利保護保険一法的ファイナンスの規範論序説一』成文堂。 太田勝造（1997）「弁護士報酬をめぐって」『ジュリスト』1112号，31-40頁。 神取道宏（2014）『ミクロ経済学の力』日本評論社。 東京弁護士会法友全期会報酬基準研究会（2004）『Q\&A 弁護士報酬ハンドブック 一これからの弁護士報酬のノウハウ』ぎょうせい。

日本弁護士連合会（2006）『アンケート結果にもとづく市民のための弁護士報酬の 目安』。

内藤和美（2016）「わが国における権利保護保険の機能と課題」『保険学雑誌』634 号87-110頁。

細江守紀（2005）『情報とインセンティブの経済学』九州大学出版会。

山下典孝（2011）「わが国に扔ける弁護士費用保険に関する一考察」(大谷孝一博 士古稀記念『保険学保険法学の課題と展望』485-502頁）成文堂。

山下典孝（2017）「依頼者保護のための制度構築に関する問題」『保険学雑誌』636 号 (本号)。

Milgrom, P. \& P. Roberts. (1992) Economics, Organization and Management, Prentice Hall.（ミルグロム\&ロバーツ著，奥野正寛ほか訳『組織の経済学』 
NTT 出版, 1997年)。

Pindyck R. S. \& D.L. Rubinfeld. (2008) Microeconomics, 7 th Edition, Prentice Hall. (ピンダイク \&ルビンフェルド著, 姉川知史監訳『ミクロ経済学 I』中経出版, 2014年)。

Scotchmer, S. \& D. L. Rubinfeld. ( 1990 ) "Contingent Fees for Attorneys: An Economic Analysis," RAND Journal of Economics 24, pp 343-356.

Rasmusen, E. B. ( 1998 ) "Nuisance Suits," The New Palgrave Dictionary of Economics and the Law, Volume 2, pp 690-693, (Peter Newman, ed.), Macmillan Reference Limited.

Toothman J. W. \& G. R. William (2003) Legal Fees: Law and Management, Carolina Academic Press.

Varian H.R. (2014) Intermediate Microeconomics: A Modern Approach, Ninth Edition, W. W. Norton \& Company, Inc. (ヴァリアン著, 佐藤隆三監訳, 大住栄 治ほか訳『入門ミクロ経済学』原著第 9 版，勁草書房，2015年）。 